\title{
FATAL ACCIDENT INVOLVEMENT RATES BY DRIVER AGE FOR LARGE TRUCKS
}

\author{
KenNETh L. CAMPBell \\ The University of Michigan, Transportation Research Institute, \\ Ann Arbor, Michigan, U.S.A.
}

(Received 27 July 1989; in revised form 5 September 1990)

\begin{abstract}
Survey data on large trucks involved in fatal accidents and on the travel of large trucks provide estimates of fatal accident involvement rates by driver age. The analysis is focused on the implications of lowering the minimum age for drivers of commercial trucks operating interstate from 21 to 19 years. Fatal accident involvement rates for drivers of large trucks are found to increase with decreasing driver age. The younger drivers are over-involved until about age 27. Drivers under the age of 21 are over-involved by a factor of 6 in comparison to the overall rate for all drivers. Other factors known to have significant influences on the probability of involvement in a fatal accident were examined to determine their association with the overinvolvement of younger drivers. The general pattern of over-involvement for younger drivers pervades virtually every combination of factors examined. Thus, it is concluded that the basic trend with driver age shown in the aggregate data is primarily associated with age and is not associated with the other factors examined. The results of this analysis substantiate an elevated risk of fatal accident involvement for younger drivers of large trucks.
\end{abstract}

\section{INTRODUCTION}

The minimum age for drivers of commercial vehicles engaged in interstate commerce is currently 21 years. Previous studies have examined accident rates of passenger vehicles in relation to the age of the driver. Williams (1985) focused on the involvement rates of teenage drivers in fatal accidents using the data from the 1977 National Personal Transportation Study conducted by the Bureau of the Census and from the National Highway Traffic Safety Administration (NHTSA) Fatal Accident Reporting System (FARS) files for 1976-1978. Male drivers under 19 had fatal accident involvement rates (involvements per hundred million miles) about 4-6 times the overall rate. Rates for male drivers aged 19-20 were 2-3 times the overall rate. Younger male drivers continued to be over-involved until about age 25. Williams also examined driving at night. Nighttime rates for young males are about 4 times the daytime rates, and young males did somewhat more of their driving at night as compared to older males. Young females were also over-involved in fatal accidents, and the pattern of over-involvement was very similar to that for males. However, the fatal accident involvement rates for young females were about half those of young males. All of these rates were developed for drivers of passenger vehicles only (cars, light trucks, and vans).

The probability of fatality in an accident involving a large truck is about twice as high as in accidents not involving large trucks (Eicher, Robertson, and Toth 1982). This is a direct consequence of the weight of large trucks in general and the disparity in weight between large trucks and the passenger cars that are most commonly the other vehicle involved in the accident. If the risk of fatal accident involvement for young males when they are driving commercial trucks is as high as when they are driving passenger vehicles, then the Williams study cited above indicates that, if the minimum driving age were lowered to 19 , these new drivers of commercial trucks would be expected to have fatal accident involvement rates 2-3 times the overall rate for commercial truck drivers.

Information is not available in the literature on the relationship of the age of commercial vehicle drivers to their accident experience. One might expect younger drivers to do better when they are employed to drive, particularly since their elevated rates in passenger vehicles are associated so some extent with nighttime driving and alcohol consumption. 'The basic question is the extent to which the risk of accident involvement for younger drivers of large trucks is improved in comparison to their risk as drivers of 
passenger vehicles. The Center for National Truck Statistics (CNTS) at the University of Michigan Transportation Research Institute (UMTRI) has collected survey data on fatal accidents involving large trucks and on large truck travel that will support calculation of fatal accident involvement rates by driver age. This paper describes the data, methods, and results of an analysis carried out by the author for the Federal Highway Administration (Campbell et al. 1988b).

\section{METHOD}

Calculation of fatal accident involvement rates by driver age requires data on the age of drivers of large trucks involved in fatal accidents for the numerator and the mileage traveled by large trucks broken down by the age of the driver for the denominator. Over the past several years, UMTRI has conducted national surveys of fatal accidents involving large trucks and of the travel of large trucks. These survey files provide the necessary data for this analysis of fatal accident involvement rates by driver age. Each is described briefly in the following paragraphs.

In 1981, a survey of all large trucks involved in fatal accidents in the United States was initiated, with 1980 being the first year covered. This survey combines information from the NHTSA Fatal Accident Reporting System (FARS) with accident data from the MCS 50-T report submitted to the FHWA Office of Motor Carriers by interstate carriers, the original police accident reports, and comprehensive telephone surveys conducted by UMTRI staff to produce the data file called Trucks Involved in Fatal Accidents (TIFA). Essentially, the file has the data elements from both FARS and the MCS 50-T form with complete national coverage of both interstate and intrastate carriers. Pickup trucks are excluded from the survey, as are all passenger vehicles (vans, utility vehicles, buses, and ambulances) and fire trucks. Otherwise, all trucks with a gross vehicle weight rating greater than 10,000 pounds are included. Trucks involved in fatal accidents in Alaska and Hawaii are excluded. The TIFA files are currently complete for five years, 1980-1984. More than 25,000 large trucks were involved in fatal accidents over that period. A more complete description of the TIFA files is provided by Carsten and Pettis (1987), along with one-way tabulations of every variable in the five-year file.

In 1985, the National Truck Trip Information Survey (NTTIS) was initiated. For this survey, the owners of nearly 5,000 large trucks were contacted four times over a 12-month period to obtain detailed information on the use of the truck. The information collected includes the configuration, cargo, actual weight, and the route the truck followed. The NTTIS began with a probability-based sample of trucks registered in the United States as of July 1, 1983. The sample was drawn from registration records maintained by R. L. Polk and Company, Cincinnati division.

For each survey-day, the owner was asked to describe every trip made by the selected truck. Trips were split by time of day into day and night, and each trip was mapped on special atlases prepared by UMTRI. These maps show the boundaries of every urban area having a population over 5,000 based on FHWA definitions obtained from each state. Roads are classified as limited access, other major or primary highways (largely U.S. and state routes), and other roads (mostly county roads and city streets). By mapping out the travel, each mile is characterized by the actual loading and configuration of the vehicle including the driver age. Each mile is also categorized by road type, rural/ urban area, and day/night. Travel estimates are computed from the trip-level files by summing across trips and across the categories defined by the levels of each of the desired factors (vehicle type. carrier type, road type, etc.). A complete description of the NTTIS data is provided by Blower and Pettis (1988). The combination of the accident data in TIFA with miles traveled from NTTIS provides estimates of fatal accident involvement rates.

The "relative risk" is used for this analysis to facilitate comparisons. Relative risk is calculated by dividing the raw rates (fatal accident involvements per hundred million vehicle miles) for every subset by the overall raw rate. The overall relative risk, then, is 1.0. Subsets with a relative risk less than 1.0 are under-involved in comparison to the 
overall rate, and subsets with a relative risk greater than 1.0 are over-involved. The relative risk is also equal to the proportion of involvements for the subset divided by the proportion of travel for the subset. For example, if a subset has $10 \%$ of the involvements and $5 \%$ of the travel, the relative risk is $10 / 5$, or 2.0 . The actual number of involvements, estimated travel, and raw rates for each category are shown in the tables in this report.

The rates are based on the five-year TIFA file (1980-1984) and the NTTIS file. Since the travel survey was mostly conducted in 1986, the time period for the exposure does not match the time period of the accidents, although the vehicle population in terms of distribution by model year is fairly comparable for the 1980-1984 TIFA and the NTTIS files. Obviously, it would have been more desirable to have travel data for the same period of time as the involvements, but the availability of funding and other problems preclude a better match at this time. It will be another year before the 1986 TIFA file is complete, and several years of accident data are needed to produce sufficient sample sizes. When considering possible conclusions based on the results of these analyses, the reader must remember the mismatch in time periods between the involvements and the travel. The author believes that the percent distributions across the factors presented are quite stable over time. Although the raw rates may vary, the relative risk should be more stable.

\section{FINDINGS}

The relative risk of fatal accident involvement for large trucks of all types is shown in Fig. 1 by driver age group. It should be noted here that nearly $98 \%$ of the drivers of large trucks involved in fatal accidents from 1980-1984 were male. Although the females were not actually excluded from the tabulations, the results essentially describe the experience of male drivers. Except for the first and last group, ages have been combined into two-year groups to provide sufficient sample sizes. The overall trend shown in this figure, and in particular the over-involvement of younger drivers, is very similar to the findings of Williams (1985) cited earlier. Drivers under the age of 19 are over-involved by a factor of 4 , and drivers aged 19-20 are over-involved by a factor of 6 . Drivers of large trucks continue to be over-involved through age 26 . The only difference that one notices in comparing the trend in Fig. 1 with Williams's (1985) findings for drivers of passenger vehicles is that Fig. 1 shows the under-19 group to be somewhat lower than the 19-20 age group rather than continuing the upward trend expected. Even when combined into a three-year group, the sample sizes for drivers of large trucks under age 19 are very small. This group accounts for less than .2\% of the travel and less than $.8 \%$

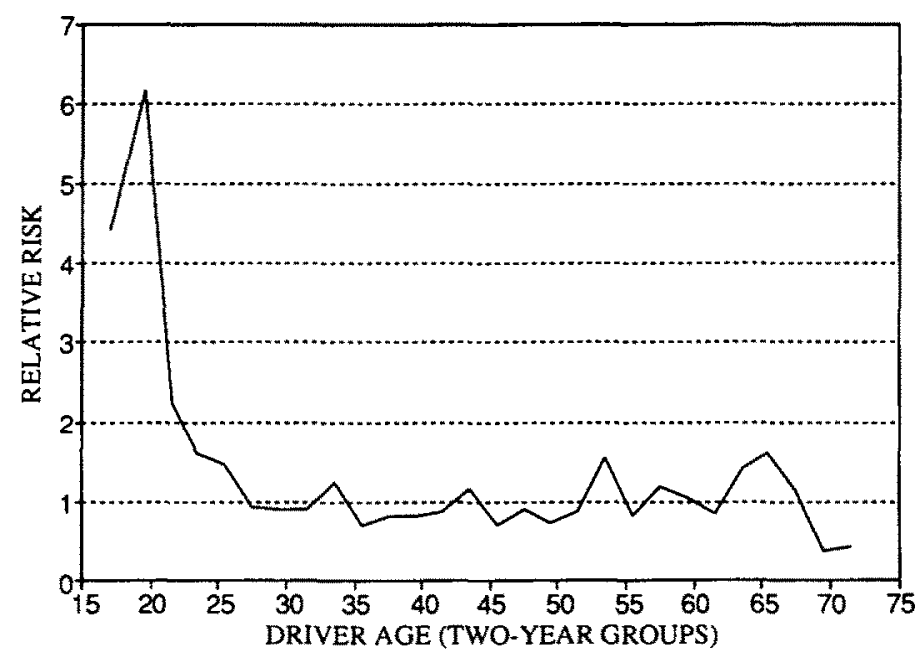

Fig. 1. Risk of fatal accident involvement by driver age. 
Table 1. Fatal accident involvement rates by 28 truck driver age groups for all truck types-NTTIS and 1980-84 TIFA Files

\begin{tabular}{|c|c|c|c|c|c|c|}
\hline $\begin{array}{c}\text { Driver Age } \\
\text { Group }\end{array}$ & $\begin{array}{c}10^{8} \\
V M T\end{array}$ & $\begin{array}{l}\text { Column } \\
\text { Percent }\end{array}$ & $\begin{array}{l}\text { Involve } \\
\text { ments }\end{array}$ & $\begin{array}{l}\text { Column } \\
\text { Percent }\end{array}$ & $\begin{array}{l}\text { Raw } \\
\text { Rate }\end{array}$ & $\begin{array}{c}\text { Relative }^{\mathbf{a}} \\
\text { Risk }\end{array}$ \\
\hline $\begin{array}{l}\text { Under } 19 \\
19-20\end{array}$ & $\begin{array}{l}0.92 \\
2.02\end{array}$ & $\begin{array}{l}0.18 \% \\
0.39\end{array}$ & $\begin{array}{l}187 \\
574\end{array}$ & $\begin{array}{l}0.78 \% \\
2.39\end{array}$ & $\begin{array}{l}40.45 \\
56.72\end{array}$ & $\begin{array}{l}4.39 \\
6.16\end{array}$ \\
\hline $\begin{array}{l}21-22 \\
23-24 \\
25-26 \\
27-28 \\
29-30\end{array}$ & $\begin{array}{l}10.12 \\
19.11 \\
24.27 \\
40.14 \\
38.51\end{array}$ & $\begin{array}{l}1.94 \\
3.66 \\
4.65 \\
7.69 \\
7.38\end{array}$ & $\begin{array}{l}1049 \\
1420 \\
1632 \\
1716 \\
1585\end{array}$ & $\begin{array}{l}4.37 \\
5.91 \\
6.79 \\
7.14 \\
6.60\end{array}$ & $\begin{array}{r}20.72 \\
14.86 \\
13.45 \\
8.55 \\
8.23\end{array}$ & $\begin{array}{l}2.25 \\
1.61 \\
1.46 \\
0.93 \\
0.89\end{array}$ \\
\hline $\begin{array}{l}31-32 \\
33-34 \\
35-36 \\
37-38 \\
39-40\end{array}$ & $\begin{array}{l}37.33 \\
25.44 \\
44.81 \\
34.05 \\
34.86\end{array}$ & $\begin{array}{l}7.15 \\
4.87 \\
8.59 \\
6.52 \\
6.68\end{array}$ & $\begin{array}{l}1541 \\
1466 \\
1438 \\
1283 \\
1280\end{array}$ & $\begin{array}{l}6.42 \\
6.10 \\
5.99 \\
5.34 \\
5.33\end{array}$ & $\begin{array}{r}8.26 \\
11.53 \\
6.42 \\
7.54 \\
7.34\end{array}$ & $\begin{array}{l}0.90 \\
1.25 \\
0.70 \\
0.82 \\
0.80\end{array}$ \\
\hline $\begin{array}{l}41-42 \\
43-44 \\
45-46 \\
47-48 \\
49-50\end{array}$ & $\begin{array}{l}28.93 \\
20.10 \\
30.11 \\
21.30 \\
25.02\end{array}$ & $\begin{array}{l}5.54 \\
3.85 \\
5.77 \\
4.08 \\
4.79\end{array}$ & $\begin{array}{r}1160 \\
1059 \\
992 \\
888 \\
844\end{array}$ & $\begin{array}{l}4.83 \\
4.41 \\
4.13 \\
3.70 \\
3.51\end{array}$ & $\begin{array}{r}8.02 \\
10.54 \\
6.59 \\
8.34 \\
6.75\end{array}$ & $\begin{array}{l}0.87 \\
1.14 \\
0.72 \\
0.91 \\
0.73\end{array}$ \\
\hline $\begin{array}{l}51-52 \\
53-54 \\
55-56 \\
57-58 \\
59-60\end{array}$ & $\begin{array}{r}20.16 \\
11.27 \\
17.39 \\
9.13 \\
8.57\end{array}$ & $\begin{array}{l}3.86 \\
2.16 \\
3.33 \\
1.75 \\
1.64\end{array}$ & $\begin{array}{l}810 \\
805 \\
649 \\
496 \\
415\end{array}$ & $\begin{array}{l}3.37 \\
3.35 \\
2.70 \\
2.07 \\
1.73\end{array}$ & $\begin{array}{r}8.04 \\
14.28 \\
7.46 \\
10.86 \\
9.68\end{array}$ & $\begin{array}{l}0.87 \\
1.55 \\
0.81 \\
1.18 \\
1.05\end{array}$ \\
\hline $\begin{array}{l}61-62 \\
63-64 \\
65-66 \\
67-68 \\
69-70\end{array}$ & $\begin{array}{l}7.12 \\
2.78 \\
1.22 \\
1.42 \\
2.77\end{array}$ & $\begin{array}{l}1.37 \\
0.53 \\
0.23 \\
0.27 \\
0.53\end{array}$ & $\begin{array}{r}278 \\
179 \\
90 \\
74 \\
48\end{array}$ & $\begin{array}{l}1.16 \\
0.75 \\
0.37 \\
0.31 \\
0.20\end{array}$ & $\begin{array}{r}7.80 \\
12.89 \\
14.78 \\
10.39 \\
3.47\end{array}$ & $\begin{array}{l}0.85 \\
1.40 \\
1.61 \\
1.13 \\
0.38\end{array}$ \\
\hline Over 70 & 3.00 & 0.58 & 60 & 0.25 & 4.00 & 0.43 \\
\hline Total & 521.91 & $100.00 \%$ & 24018 & $100.00 \%$ & 9.20 & 1.00 \\
\hline
\end{tabular}

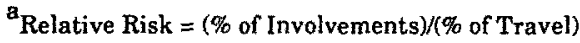

of the fatal accidents, as shown in Table 1. Drivers aged 19-20 accounted for only .4\% of the travel and $2.4 \%$ of the fatal accidents. With these small sample sizes, such differences are not likely to be statistically significant. These statistics underscore the pervasiveness of the current minimum driving age.

Having prepared Fig. 1 showing the overall relationship of driver age to fatal accident involvement rates for large trucks of all types, the next objective was to examine the extent to which other factors were associated with driver age in general and the younger drivers in particular. A previous analysis of large truck fatal accident rates (Campbell et al. 1988a) has shown substantial differences in the probability of involvement associated with factors such as time of day (day as 6:00 A.M. to 9:00 P.M. and night as 9:00 P.M. to 6:00 A.M.), truck type (single-unit versus combination), and road type (limitedaccess versus nonlimited). For example, on rural limited-access roads, the probability of fatal accident involvement is three times higher at night than in the day. For rural daytime travel, the probability of fatal accident involvement is five times higher on nonlimited-access roads as compared to limited-access. If factors such as these are associated with the driving experience of younger drivers, they might contribute to, or be partially responsible for, the apparent over-involvement of the younger drivers. These factors were examined separately and in combination by partitioning the data according to the levels of the factor, or combination of factors, and then calculating fatal accident involvement rates in each age group. Comparison among the age groups can be made within each level and combination of levels of the factors defining the subgroup. The overall rate for the subgroup is indicative of the risk associated with the subgroup itself.

The relative risk of nighttime versus daytime operation is shown by driver age group in Fig. 2. For this analysis, the age groups were expanded to five years to maintain sample size except for the first two groups, under 25 , and the last group. Figure 2 and 


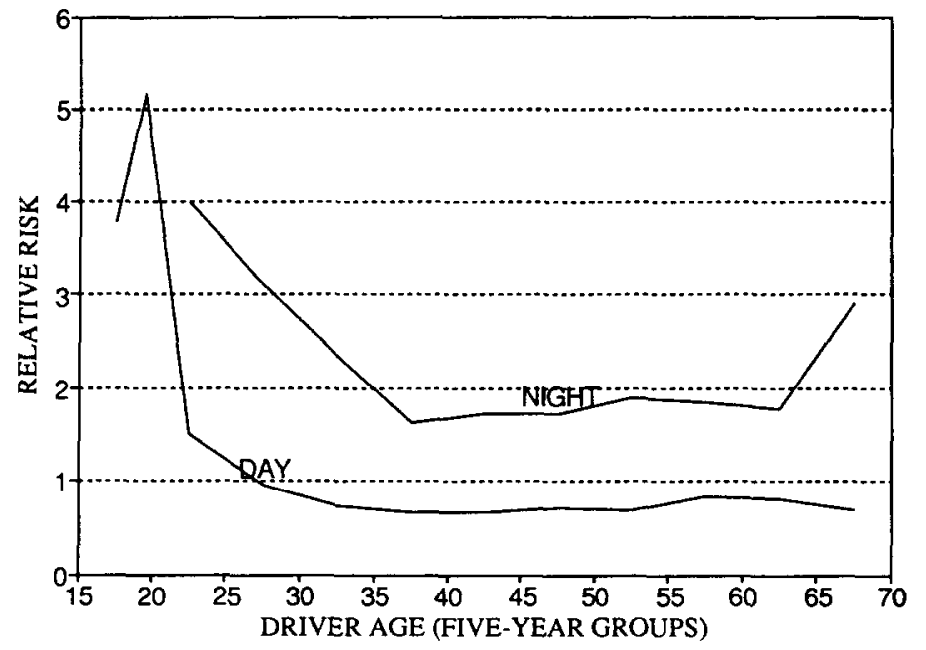

Fig. 2. Daytime vs. nighttime risk of fatal accident involvement by driver age.

Table 2 illustrate that overall, the fatal accident rate is more than double at night as compared with daytime. The over-involvement of the younger drivers is comparable in both the daytime and the nighttime. As an aside, it is interesting that the older drivers are not further over-involved at night. One might have expected the generally poorer nighttime visual acuity of older drivers to be reflected in these accident rates. Mortimer and Fell (1988) found males over 65 to be over-involved in fatal accidents at night as drivers of passenger vehicles, but under-involved as drivers of large trucks. Apparently,

Table 2. Fatal accident involvement rates by 12 driver age groups for day vs. night-NTTIS and 1980-84 TIFA Filẹs

\begin{tabular}{|c|c|c|c|c|c|c|}
\hline $\begin{array}{c}\text { Driver Age } \\
\text { Group }\end{array}$ & $\begin{array}{c}10^{8} \\
\text { VMT }\end{array}$ & $\begin{array}{l}\text { Column } \\
\text { Percent }\end{array}$ & $\begin{array}{c}\text { Involve } \\
\text { ments }\end{array}$ & $\begin{array}{l}\text { Column } \\
\text { Percent }\end{array}$ & $\begin{array}{l}\text { Raw } \\
\text { Rate }\end{array}$ & $\begin{array}{c}\text { Relative }^{\mathbf{a}} \\
\text { Risk }\end{array}$ \\
\hline \multicolumn{7}{|c|}{ DAY (6AM-9PM) } \\
\hline $\begin{array}{l}\text { Under } 19 \\
19-20 \\
21-24 \\
25-29 \\
30-34 \\
35-39 \\
40-44 \\
45-49 \\
50-54 \\
55-59 \\
60-64 \\
\text { Over } 64\end{array}$ & $\begin{array}{r}0.86 \\
1.87 \\
25.07 \\
63.06 \\
74.19 \\
70.81 \\
58.64 \\
45.53 \\
40.37 \\
23.66 \\
11.92 \\
6.66\end{array}$ & $\begin{array}{c}0.18 \% \\
0.38 \\
5.10 \\
12.82 \\
15.08 \\
14.39 \\
11.92 \\
9.25 \\
8.21 \\
4.81 \\
2.42 \\
1.35\end{array}$ & $\begin{array}{r}157 \\
465 \\
1841 \\
2920 \\
2594 \\
2235 \\
1871 \\
1561 \\
1344 \\
933 \\
458 \\
221\end{array}$ & $\begin{array}{c}0.66 \% \\
1.96 \\
7.77 \\
12.32 \\
10.95 \\
9.43 \\
7.89 \\
6.59 \\
5.67 \\
3.94 \\
1.93 \\
0.93\end{array}$ & $\begin{array}{r}36.39 \\
49.71 \\
14.69 \\
9.26 \\
6.99 \\
6.31 \\
6.38 \\
6.86 \\
6.66 \\
7.89 \\
7.69 \\
6.64\end{array}$ & $\begin{array}{l}3.78 \\
5.16 \\
1.52 \\
0.96 \\
0.73 \\
0.66 \\
0.66 \\
0.71 \\
0.69 \\
0.82 \\
0.80 \\
0.69\end{array}$ \\
\hline SUBTOTAL & 422.64 & 85.91 & 16600 & 70.05 & 7.86 & 0.82 \\
\hline \multicolumn{7}{|c|}{ NIGHT (9PM-6AM) } \\
\hline $\begin{array}{l}\text { Under } 19 \\
19-20 \\
21-24 \\
25-29 \\
30-34 \\
35-39 \\
40-44 \\
45-49 \\
50-54 \\
55-59 \\
60-64 \\
\text { Over } 64\end{array}$ & $\begin{array}{r}0.00 \\
0.00 \\
3.02 \\
8.03 \\
9.98 \\
13.74 \\
11.54 \\
8.54 \\
7.28 \\
4.73 \\
2.09 \\
0.33\end{array}$ & $\begin{array}{l}0.00 \% \\
0.00 \\
0.61 \\
1.63 \\
2.03 \\
2.79 \\
2.35 \\
1.74 \\
1.48 \\
0.96 \\
0.43 \\
0.07\end{array}$ & $\begin{array}{r}29 \\
96 \\
583 \\
1197 \\
1135 \\
1075 \\
961 \\
714 \\
664 \\
421 \\
178 \\
46\end{array}$ & $\begin{array}{l}0.12 \% \\
0.41 \\
2.46 \\
5.05 \\
4.79 \\
4.54 \\
4.06 \\
3.01 \\
2.80 \\
1.78 \\
0.75 \\
0.19\end{array}$ & $\begin{array}{r}- \\
38.55 \\
29.80 \\
22.74 \\
15.65 \\
16.66 \\
16.71 \\
18.24 \\
17.80 \\
17.01 \\
28.13\end{array}$ & $\begin{array}{l}-\overline{-} \\
4.00 \\
3.09 \\
2.36 \\
1.62 \\
1.73 \\
1.73 \\
1.89 \\
1.85 \\
1.77 \\
2.92\end{array}$ \\
\hline SUBTOTAL & 69.30 & 14.09 & 7099 & 29.95 & 20.49 & 2.13 \\
\hline $\begin{array}{l}\text { GRAND } \\
\text { TOTAL }\end{array}$ & 491.94 & $100.00 \%$ & 23699 & $100.00 \%$ & 9.63 & 1.00 \\
\hline
\end{tabular}

${ }^{a}$ Relative Risk $=(\%$ of Involvements $) /(\%$ of Travel $)$ 
among older truck drivers, other factors compensate for decreased nighttime visual acuity and other age-related factors.

The next factor examined individually was the type of truck. The relative risk of fatal accident involvement is shown by driver age group separately for single-unit trucks and combinations in Fig. 3. Single-unit trucks are those without trailers. Tractors without trailers (bobtails) are included in this group. Combination trucks are those with trailers, and this group includes both tractors and straight trucks pulling one or more trailers. Twelve driver age groups are used in this figure. Drivers under 21 are over-involved by about a factor of 6 when driving either single-unit or combination trucks. About $60 \%$ of the travel by drivers under 21 was in a single-unit truck, and only $40 \%$ was in combination trucks. Overall, combination trucks accounted for almost $70 \%$ of the largetruck travel.

The over-involvement of an age group relative to a subgroup can be obtained by dividing by the relative risk for the subgroup. From Table 3 , it can be seen that singleunit truck drivers aged 19-20 have a relative risk of 4.82 (relative to the rate for all large trucks shown as 1.00 at the bottom of Table 3 ). Single-unit trucks as a group have a relative risk of 0.80 , so that the risk for drivers aged 19-20 of single-unit trucks relative to that for all single-unit trucks is $4.82 / 0.80$, or 6.03 . The risk for drivers aged $19-20$ of combination trucks relative to the rate for all drivers of combination trucks is $9.00 / 1.09$, or 8.99 . Thus, the over-involvement of younger drivers of both single-unit and combination trucks, 6.03 and 8.99 , is quite similar when compared to the overall rate for the respective vehicle type.

Other factors were also examined. Eight travel categories were formed from all possible combinations of three two-level travel factors. They are road type (limitedaccess vs. non-limited-access), area type (rural versus urban), and time of day recoded into "day" (6:00 A.M.-9:00 P.M.) and "night" (9:00 P.M.-6:00 A.M.). An examination of the distribution of travel for younger drivers across the eight travel categories revealed that they traveled somewhat more on non-limited-access roads during the day, but somewhat less on limited-access roads at night. Adjusted rates were calculated to remove these differences from the comparison of younger drivers to all drivers. However, the adjusted rates are not appreciably different from the original rates. For drivers under 25 , the adjusted rate was 2.17 as compared with the unadjusted rate of 2.15 . This calculation indicates that differences in the type of travel of younger drivers is not responsible for their over-involvement in the aggregate data. Relative risks were also compared for each of the eight travel categories. The younger drivers were over-involved in each driving environment.

Another factor examined was the split between interstate carriers and intrastate carriers. For this tabulation, the eight travel categories have been reduced to four by

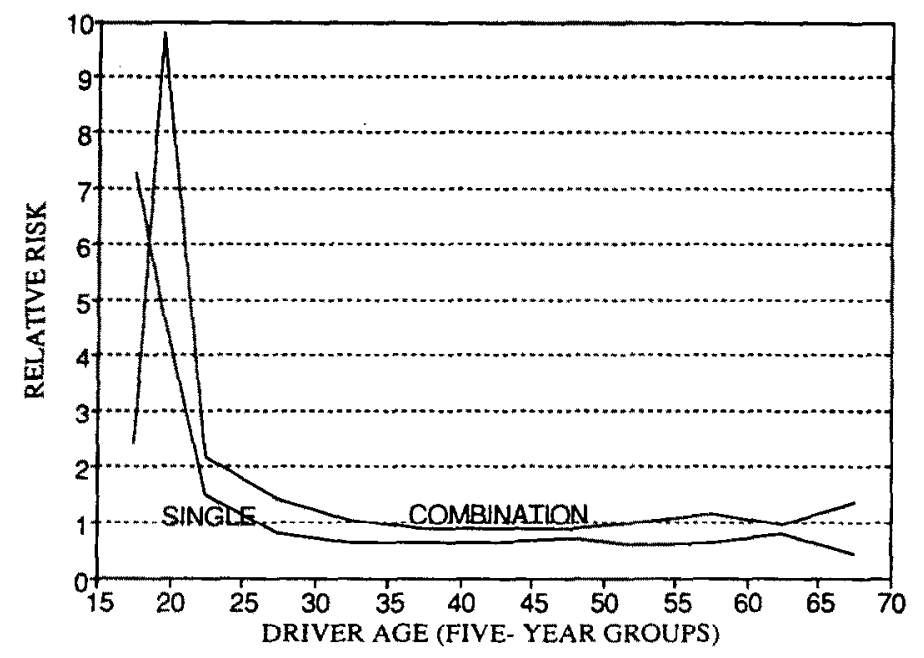

Fig. 3. Single-unit vs. combination truck risk of fatal accident involvement by driver age. 
Table 3. Fatal accident involvement rates by 12 driver age groups for single-unit and combination trucks-NTTIS and 1980-84 TIFA Files

\begin{tabular}{|c|c|c|c|c|c|c|}
\hline $\begin{array}{l}\text { Driver Age } \\
\text { Group }\end{array}$ & ${ }_{\mathrm{VMT}}^{10^{8}}$ & $\begin{array}{l}\text { Column } \\
\text { Percent }\end{array}$ & $\begin{array}{l}\text { Involve } \\
\text { ments }\end{array}$ & $\begin{array}{l}\text { Column } \\
\text { Percent }\end{array}$ & $\begin{array}{l}\text { Raw } \\
\text { Rate }\end{array}$ & $\begin{array}{c}\text { Relative }^{\mathbf{a}} \\
\text { Risk }\end{array}$ \\
\hline \multicolumn{7}{|c|}{ SINGLE-UNIT } \\
\hline $\begin{array}{l}\text { Under } 19 \\
19-20 \\
21-24 \\
25-29 \\
30-34 \\
35-39 \\
40-44 \\
45-49 \\
50-54 \\
55-59 \\
60-64 \\
\text { Over } 64\end{array}$ & $\begin{array}{r}0.36 \\
1.39 \\
13.99 \\
28.63 \\
29.85 \\
22.72 \\
18.26 \\
13.99 \\
14.89 \\
9.55 \\
4.79 \\
6.30\end{array}$ & $\begin{array}{l}0.07 \% \\
0.27 \\
2.69 \\
5.51 \\
5.74 \\
4.37 \\
3.51 \\
2.69 \\
2.86 \\
1.84 \\
0.92 \\
1.21\end{array}$ & $\begin{array}{r}120 \\
306 \\
944 \\
1066 \\
856 \\
683 \\
524 \\
473 \\
408 \\
293 \\
174 \\
133\end{array}$ & $\begin{array}{l}0.51 \% \\
1.29 \\
3.99 \\
4.51 \\
3.62 \\
2.89 \\
2.21 \\
2.00 \\
1.72 \\
1.24 \\
0.74 \\
0.56\end{array}$ & $\begin{array}{r}66.56 \\
43.91 \\
13.50 \\
7.45 \\
5.73 \\
6.01 \\
5.74 \\
6.76 \\
5.48 \\
6.14 \\
7.26 \\
4.22\end{array}$ & $\begin{array}{l}7.31 \\
4.82 \\
1.48 \\
0.82 \\
0.63 \\
0.66 \\
0.63 \\
0.74 \\
0.60 \\
0.67 \\
0.80 \\
0.46\end{array}$ \\
\hline SUBTOTAL & 164.72 & 31.68 & 5980 & 25.28 & 7.26 & 0.80 \\
\hline \multicolumn{7}{|c|}{ COMBINATIONS } \\
\hline $\begin{array}{l}\text { Under } 19 \\
19-20 \\
21-24 \\
25-29 \\
30-34 \\
35-39 \\
40-44 \\
45-49 \\
50-54 \\
55-59 \\
60-64 \\
\text { Over } 64\end{array}$ & $\begin{array}{r}0.56 \\
0.57 \\
14.85 \\
47.24 \\
59.55 \\
65.11 \\
56.41 \\
43.34 \\
34.75 \\
20.39 \\
10.28 \\
2.11\end{array}$ & $\begin{array}{c}0.11 \% \\
0.11 \\
2.86 \\
9.09 \\
11.45 \\
12.52 \\
10.85 \\
8.34 \\
6.68 \\
3.92 \\
1.98 \\
0.41\end{array}$ & $\begin{array}{r}62 \\
255 \\
1482 \\
3023 \\
2871 \\
2633 \\
2293 \\
1800 \\
1606 \\
1061 \\
460 \\
133\end{array}$ & $\begin{array}{c}0.26 \% \\
1.08 \\
6.26 \\
12.78 \\
12.13 \\
11.13 \\
9.69 \\
7.61 \\
6.79 \\
4.48 \\
1.94 \\
0.56\end{array}$ & $\begin{array}{r}21.98 \\
89.24 \\
19.96 \\
12.80 \\
9.64 \\
8.09 \\
8.13 \\
8.31 \\
9.24 \\
10.41 \\
8.95 \\
12.60\end{array}$ & $\begin{array}{l}2.41 \\
9.80 \\
2.19 \\
1.41 \\
1.06 \\
0.89 \\
0.89 \\
0.91 \\
1.02 \\
1.14 \\
0.98 \\
1.38\end{array}$ \\
\hline SUBTOTAL & 355.16 & 68.32 & 17679 & 74.72 & 9.94 & 1.09 \\
\hline $\begin{array}{l}\text { GRAND } \\
\text { TOTAL }\end{array}$ & 519.87 & $100.00 \%$ & 23659 & $100.00 \%$ & 9.10 & 1.00 \\
\hline
\end{tabular}

${ }^{a}$ Relative Risk $=(\%$ of Involvements $) /(\%$ of 'Travel $)$

omitting the rural/urban split. In order to maintain sample sizes, ages were combined into five groups: under $25,25-34,35-44,45-54$, and over 54 . These, in turn, are shown for four subsets: single-unit trucks in interstate operation, single-units in intrastate operation, combination trucks in interstate operation, and combinations in intrastate operation. The inter-vs. intrastate distinction is made at the level of the carrier, or owner. If any of the carrier's trucks operate interstate, then all of the travel of the trucks operated by that carrier is designated as interstate. Conversely, all of the trucks operated by an intrastate carrier operate within a single state.

Combination trucks in interstate operation are the largest of the four major divisions and account for almost $60 \%$ of all large truck travel. Combinations in intrastate operation account for about $12 \%$ of the large truck travel, a group comparable in travel to each of the single-unit groups. The results for the under- 25 age group can be summarized for the four major divisions by aggregating the rates for this age group across the four travel categories in each truck type/operation and calculating the relative risk with respect to the overall rate for the truck type/operation, as described previously. When summarized in this way, the over-involvement of the under- 25 group by truck type/operation is as follows:

Single-unit/interstate 2.06

Single-unit/intrastate 2.45

Combination/interstate 2.33

Combination/intrastate 1.75

Overall, these results do not vary appreciably from the 2.15 rate for the aggregate. The overall trend of over-involvement pervades every type of vehicle and operation examined. 
Information on the driver is carried over from the NHTSA FARS files to the TIFA file. Tabulations of these variables were prepared comparing the drivers under 21 with truck drivers of all ages. For the years 1980-1984, there were a total of 24,119 drivers of large trucks involved in fatal accidents that were included in the tabulations. Of these, $747(3.1 \%)$ were under 21 . Twice as many of the drivers under 21 had an invalid license as compared with all drivers. That is, $12.4 \%$ of the drivers under 21 did not have a valid license at the time of the accident as compared to $5.3 \%$ of all truck drivers involved in fatal accidents. About $25 \%$ of the drivers under 21 were charged with a violation in connection with the accident as compared with only $15 \%$ for truck drivers of all ages in fatal accidents. The types of violations the younger drivers were more frequently charged with included speeding, other moving violations, and violations of unknown type. However, only $2.4 \%$ of the drivers under 21 were identified as "had been drinking" as compared to $3.3 \%$ of all truck drivers. Perhaps the most suggestive variable available is the one identifying driver-related factors. Overall, no driver related factor is coded for $60 \%$ of the truck drivers, whereas no factor is coded for $45 \%$ of the drivers under 21. Most of the factors coded are grouped as "miscellaneous causes." These include following improperly, failure to keep in lane (and ran off road), reckless operation, driving too fast, and many others. One of these miscellaneous causes was coded for $45 \%$ of the drivers under 21 as compared with $31 \%$ for all drivers. The available accident data do not identify the underlying causes of the over-involvement of younger drivers. However, the factors that are associated with the younger drivers suggest a lack of maturity and judgment.

\section{DISCUSSION}

The most significant finding is the pervasive nature of the over-involvement of young drivers. Williams (1985) described the effectiveness of curfews in limiting nighttime driving among teens in passenger vehicles. Nighttime is associated with a higher risk of fatal accident involvement for drivers of all ages and for all types of vehicles. Limiting nighttime driving may be an appropriate countermeasure for teenage drivers of passenger vehicles, since driving after dark may be less essential and it carries the greatest risk. Although curfews are effective in that they reduce the exposure in the high risk periods, they do not in any way modify the general over-involvement of this group when they do drive. If one is considering lowering the minimum driving age for commercial vehicles, then the significant finding of this analysis is that the younger drivers are over-involved in virtually all of the conditions examined in this study. They are over-involved in the day just as much as at night, on all types of roads, and in both rural and urban areas. Furthermore, younger drivers are over-involved as drivers of commercial vehicles to about the same degree as when they are drivers of passenger vehicles. The fact that they are employed to drive commercial vehicles apparently does not alter the essential pattern of over-involvement that is shown when they drive passenger vehicles.

Adjustment of the rates by age category for road type, day/night, and rural/urban area did not appreciably alter the pattern of over-involvement. Since this trend was not found to be a consequence of travel factors known to have rather large effects individually, and since the trend was exhibited in every subset examined, the author concludes that it is appropriate to regard the rates by age group in the aggregate data as primarily associated with age and not the other factors examined here. The advantage of aggregating the data for all large trucks is that sample sizes are increased for the younger age groups of interest here.

The fatal accident involvement rates calculated from the UMTRI survey data for large truck drivers aged 19-20 are about double the rates presented by Williams for male drivers of the same age. This result is consistent with the statistics reported by Eicher et al. (1982) indicating that the probability of fatality in accidents involving a large truck is about double that of accidents not involving a large truck. The results of this analysis, then. indicate a risk of fatal accident involvement for young drivers of large trucks that is consistent with their pattern of over-involvement as drivers of passenger vehicles. 
In closing, it should be pointed out that although these findings substantiate a high risk for young drivers of large trucks, they do not identify the fundamental causes of this risk. It would seem that the driving situation for young drivers of trucks would be much different than for young drivers of passenger vehicles. The nighttime driving with peers and associated alcohol consumption that characterizes teenage passenger car use is much less likely be a part of their truck driving. However, truck driving is a more demanding task. Training and experience may be more important. Unfortunately, years of experience is not coded in the accident files used for this analysis. Although this analysis does not shed any light on the fundamental causes of the over-involvement of younger drivers, it does illuminate the likely consequences if the minimum age for commercial drivers is lowered without addressing this fundamental problem.

\section{REFERENCES}

Blower. D. F.; Pettis. L. C. National truck trip information survey (nttis). Report No. UMTRI-88-11. Ann Arbor, MI: The University of Michigan Transportation Research Institute; 1988.

Campbell, K. L.; Blower, D. F.; Gattis, R. G.; Wolfe, A. C. Analysis of accident rates of heavy-duty vehicles. Report No. UMTRI-88-17. Ann Arbor, MI: The University of Michigan Transportation Research Institute; $1988 \mathrm{a}$.

Campbell, K. L.; Wolfe, A. C. Fatal accident involvement rates by driver age for large trucks. Report No. UMTRI-88-43. Ann Arbor, MI: Transportation Research Institute, The University of Michigan; 1988b.

Carsten, O. M. C.; Pettis, L. C. Trucks involved in fatal accidents, 1980-84, by power unit type. Report No. UMTRI-87-38. Ann Arbor, MI: The University of Michigan Transportation Research Institute: 1987.

Eicher, J. P.; Robertson, H. D.; Toth, G. R. A report to Congress on large-truck accident causation. DOT/ HS-806-300. Springfield, VA: National Technical Information Service; 1982.

Mortimer, G. R.; Fell, J. C. Older drivers: Their night fatal crash involvement. 32nd annual proceedings of the Association for the Advancement of Automotive Medicine. Des Plaines, IL: AAAM, 1988: 327-342.

Williams, A. F. Nighttime driving and fatal crash involvement of teenagers. Accid. Anal. Prev. 17:1-5; 1985. 